\title{
Seed Viability and RNA Extraction Methods of Erythrina velutina Under Drought Stress
}

\author{
Juliana L. Souza ${ }^{1}$, Bruno A. L. de Freitas ${ }^{2}$, Laura C. D. P. Lima ${ }^{3}$, Valdinete V. Nunes ${ }^{1}$, Maria F. O. Torres ${ }^{1}$ \\ \& Renata Silva-Mann ${ }^{1}$ \\ ${ }^{1}$ Programa de Pós-graduação em Agricultura e Biodiversidade, Universidade Federal de Sergipe, São Cristóvão, \\ Brazil \\ ${ }^{2}$ Departamento de Fitotecnia, Universidade Federal de Viçosa, Viçosa, Brazil \\ ${ }^{3}$ Departamento de Engenharia Agronômica, Universidade Federal de Sergipe, São Cristóvão, Brazil \\ Correspondence: Juliana L. Souza, Programa de Pós-graduação em Agricultura e Biodiversidade, Universidade \\ Federal de Sergipe, São Cristóvão, Sergipe, Brazil. E-mail: juliana_lopes_souza@live.com
}

Received: June 2, $2020 \quad$ Accepted: August 3, $2020 \quad$ Online Published: November 15, 2020

doi:10.5539/jas.v12n12p192 URL: https://doi.org/10.5539/jas.v12n12p192

\begin{abstract}
Abiotic stress caused by rigorous environmental conditions, such as drought, has negative effects on seeds. The species from arid and semiarid areas have mechanisms to maintain seed viability. In this study, the analyses of physical and physiological quality of the seeds of Erythrina velutina and their response to drought stress and RNA extraction methods were carried out. The seeds were collected from mother trees in two different provenances of natural occurrences of the species. The physical quality, viability, and vigor of the seeds were evaluated by morphometric parameters, germination, and electrical conductivity tests. The seeds were submitted to drought stress conditions for $0,24,48$, and 72 hours on $-0.8 \mathrm{MPa}$ polyethylene glycol solution. To evaluate the viable RNA extraction method, the seed embryos were used for the extraction of this molecule and with an assessment of quantity and quality. The seeds from Pernambuco that were harvested in 2008 were bigger and presented lower vigor when in comparison to seeds that were harvested from Sergipe in 2012. The seeds under drought stress conditions presented null germination for all the treatments. After the drought stress, they were germinated on a paper substrate moistened with water, with better responses from the Lot Sergipe, 2012. The imbibition of seeds in the solution for 24 hours provides an increase in germination for less vigorous seeds, being indicated as a pre-germinative treatment. The RNA quality obtained by using a commercial extraction kit has better results, providing materials without contaminants when compared to the TRIzol method.
\end{abstract}

Keywords: seed vigor, water deficit, RNA integrity, mulungu

\section{Introduction}

Drought is a frequent condition in tropical areas, occurring in arid and semiarid regions with high temperatures and low pluviometry. In addition to the natural conditions, climatic changes induced by global warming have expanded the areas affected by drought, creating new regions with shortages of available water (Dai, 2013). In Northeast Brazil, a large semiarid area constitutes the Caatinga, a savanna like biome, with high temperatures and low precipitation, thus composing a rigorous climatic condition (Oliveira et al., 2012).

The environmental conditions during drought expose plants to abiotic stress, which is mainly caused by water deficit (Aroca et al., 2012; Claeys \& Inzé, 2013). The effects of stress can induce the production of endogenous substances toxic to plants, being mostly detrimental to RNA molecules, as a consequence of their single-stranded structure and the possible absence of repair mechanisms (Sano et al., 2016). In order to test the responses of seeds to drought stress in laboratory, germination on solutions that simulate water deficit have been performed in several studies (Ji et al., 2014; O’Donnell et al., 2013; Patanè et al., 2013). The most used is an osmotic aqueous solution of polyethylene glycol (PEG), a chemically inert and non-toxic component, which efficiently simulates water restriction without entering the plant cell (Hohl \& Schopfer, 1991; Pereira et al., 2014; Salah et al., 2015).

Besides understanding the plant's limitations to drought stress, water deficit simulations could be applied to stimulate seed tolerance. Controlled imbibition through seed osmoconditioning is a methodology that aims for partial imbibition under moderate stress conditions, without the protrusion of the radicle. The imbibition induces 
stress responses in seeds, such as by protein reserve mobilization, DNA activation by the double strain renaturation and synthesis, ATP production, and cell membrane repair (Jisha et al., 2013; Paparella et al., 2015; Ventura et al., 2012). As a result, molecular studies are important for the evaluation of the processes that are triggered by abiotic stress conditions. However, the methods that are conducted to obtain these results, such as RNA extraction for gene expression studies, require quality material, even under stress treatments.

Erythrina velutina Willd. is a native Brazilian tree, popularly known as mulungu. It occurs mainly in the Northeastern region, in the riparian forests of the Caatinga biome. It is also found in the altitude wetlands, the open ombrophylous forests, the rupestrian fields, and the savannas (Santos et al., 2013a). The species tolerates an annual pluviometry of 326 to 2,500 millimeters, and temperatures of $22.4{ }^{\circ} \mathrm{C}$ to $26.6{ }^{\circ} \mathrm{C}$, while adapting to areas of both humid and dry climates, as result of its high plasticity and wide occurrence. The biotechnological potential of the leaves and the bark of E. velutina assure its use in popular medicine as a sedative, a characteristic that is attributed to the erytrinan alkaloids (Albuquerque et al., 2007). The safety and the efficiency of its medicinal properties have been tested in animals (Marchioro et al., 2005). Consequently, studying the responses of seeds of E. velutina to drought stress would improve the understanding of the tolerance mechanisms that are involved in the adaptation of this species to different climatic conditions.

The objective of this study was to analyze the physiological responses of seeds of E. velutina to drought stress and to test viable methods for RNA extraction of the seeds from different provenances.

\section{Method}

The seeds of E. velutina were harvested at full maturity after fruit dehiscence (Silva et al., 2008) from Caatinga areas, in the State of Sergipe, Brazil, in 2012 (SE12), and in the State of Pernambuco, Brazil, in 2008 (PE08). They were stored in a cold room at $6{ }^{\circ} \mathrm{C}$, with $60 \%$ relative humidity, in waterproof packaging. The tests were performed in 2016. The physical quality of the seeds was assessed through morphometry and mass of 1,000 seeds. The physiological quality of the seeds was evaluated through germination and electrical conductivity tests.

\subsection{Physical Quality}

Morphometry: the seeds were measured by length, width, and thickness by a digital caliper with $0.01 \mathrm{~mm}$ accuracy.

Mass of 1,000 Seeds: the seed samples were measured for their mass in grams (g), which were calculated on an analytical balance with an accuracy of $0.001 \mathrm{~g}$, with 10 repetitions of 100 , totaling 1,000 seeds for each provenance using a protocol adapted from MAPA (2009).

\subsection{Physiological Potential}

Germination Test: the seeds were germinated in sand and on roll paper substrates according to the Rules for Seed Analysis (MAPA, 2009). The test was conducted by using four replicates, each containing 25 seeds, with a total of 100 seeds per germination substrate, for each provenance. The materials were submitted to superficial asepsis in $2 \%$ sodium hypochlorite for 5 minutes and then rinsed in distilled water. They were then mechanically scarified (Santos et al., 2013b) and germinated in paper substrate moistened with distilled water, equivalent to 2.5 times of the dry paper weight, and in sterile sand, with $60 \%$ humidity. The seeds were kept in a BOD-type (Biological Oxygen Demand) incubator germination chamber at $25{ }^{\circ} \mathrm{C}$. The parameters evaluated were germination percentage (G\%), in order to determine seed viability, and Germination Speed Index (GSI) to determine seed vigor (Maguire, 1962).

Electrical Conductivity: the test was conducted with four replicates of 25 seeds, being a total of 100 seeds per provenance. The seeds were weighed, placed in $75 \mathrm{ml}$ of distilled water for 24 hours and kept in a BOD-type germination chamber at $25^{\circ} \mathrm{C}$. The electrical conductivity was measured by using a digital conductivity meter and the results were expressed as $\mu \mathrm{S} \mathrm{cm}^{-1} \mathrm{~g}^{-1}$ (ISTA, 2006; Guedes et al., 2009).

After these evaluations, the seed samples from both origins were submitted to drought stress and the physiological parameters of viability and vigor were assessed.

\subsection{Drought Stress}

The seeds were submitted to drought stress by imbibition on paper moistened with an osmotic solution of polyethylene glycol 6000 (PEG) at $-0.8 \mathrm{MPa}$, in a volume equivalent to 2.5 times of dry paper weight (Reis et al., 2012) for $0,24,48$, and 72 hours. Subsequently, the seeds were disposed to germinate on paper moistened with distilled water, equivalent to 2.5 times of dry paper weight. The test was conducted by using four replicates, each containing 25 seeds, with a total of 100 seeds per treatment for each provenance. The seeds were kept in a 
BOD-type germination chamber at $25^{\circ} \mathrm{C}$. The parameters evaluated were germination percentage $(\mathrm{G} \%)$, in order to determine seed viability and Germination Speed Index (GSI) to determine seed vigor (Maguire, 1962).

Lastly, the molecular integrity of the embryos of the E. velutina seeds was evaluated for two RNA extraction protocols to determine a viable method after the drought stress treatment.

\subsection{RNA Extraction and the Assessment of RNA Integrity}

RNA was extracted by using TRIzol ${ }^{\circledR}$ (Invitrogen) and the commercial kit NucleoSpin ${ }^{\circledR}$ RNA II (Macherey-Nagel), according to the manufacturer's instructions. The materials that were used were the embryos from the seeds of $E$. velutina that were submitted to drought stress conditions. The extracted RNA samples were treated with DNase I, RNase-free (Thermo Scientific ${ }^{\mathrm{TM}}$ ) to remove the residual DNA contaminants. For control, the seeds were germinated without the drought stress treatment. The extracted RNA's quantity and quality were assessed through nanospectrophotometry in a spectral range of 260, 230, and $280 \mathrm{~nm}$. In order to assess the RNA integrity, $1 \mu \mathrm{g}$ RNA was applied on $1.0 \%$ agarose gel electrophoresis stained with Gel Ready ${ }^{\mathrm{TM}}$ and visualized using a UV transilluminator.

\subsection{Data Statistical Analysis}

The statistical design was completely randomized with 4 replicates of 25 seeds, totaling 100 seeds per treatment. It is important to emphasize that the species has had low seed production over recent years.

The data was analyzed in a $2 \times 4$ factorial scheme, with two provenances, and 4 drought stress conditions using polyethylene glycol PEG 6000 solution at $-0.8 \mathrm{MPa}(0,24,48$, and 72 hours). The data was submitted to an analysis of variance (ANOVA), preceded by normality and homogeneity tests, using the Shapiro-Wilk test and Bartlett's test. The mean values were then compared by the Tukey test $(p<0.05)$. The comparison of the averages of the physiological potential, with those of the treatments in the factorial scheme, was performed by Dunnett's test $(\mathrm{p}<0.05)$.

\section{Results and Discussion}

Seed viability and vigor tests enable the identification of lots with higher probability of germination, survival in field, and/or conservation under storage conditions. Through these tests, it is possible to identify the physiological differences between seed provenances and to evaluate the potential of the plant materials.

\subsection{Physical Quality}

Through the morphometry analyses, it was observed that the seeds of the Pernambuco lot were larger and had a greater mass (Table 1).

Table 1. Average length (mm), width ( $\mathrm{mm})$, thickness $(\mathrm{mm})$, and area $\left(\mathrm{mm}^{2}\right)$ of 100 seeds, and the mass of 1,000 seeds (g) from Sergipe (SE12) and Pernambuco (PE08)

\begin{tabular}{llllll}
\hline Provenance & Length $(\mathrm{mm})$ & Width $(\mathrm{mm})$ & Thickness $(\mathrm{mm})$ & Area $\left(\mathrm{mm}^{2}\right)$ & Mass of 1,000 seeds $(\mathrm{g})$ \\
\hline SE12 & $13.77 \mathrm{~b}^{*}$ & $9.46 \mathrm{a}$ & $8.46 \mathrm{~b}$ & $130.53 \mathrm{~b}$ & $42.25 \mathrm{~b}$ \\
PE08 & $14.89 \mathrm{a}$ & $9.48 \mathrm{a}$ & $9.38 \mathrm{a}$ & $141.50 \mathrm{a}$ & $53.92 \mathrm{a}$ \\
\hline
\end{tabular}

Note. ${ }^{*}$ Different letters in the same column indicate significant differences by the by the Tukey test $(\mathrm{p}<0.01)$.

Most of the seeds from Sergipe presented 13.34 to $14.03 \mathrm{~mm}$ of length (35\%), between 9.38 to 9.80 mm of width $(35 \%)$ and 8.33 to $8.81 \mathrm{~mm}$ of thickness (40\%). For the Pernambuco seeds, the length was between 14.72 to 15.41 $\mathrm{mm}(30 \%)$, the width was 8.95 to $9.38 \mathrm{~mm}(30 \%)$, and the thickness was 8.81 to $9.28 \mathrm{~mm}(35 \%)$.

In a study with E. velutina, when evaluating the seed morphometry of the Caatinga and the Brejo de Altitude (wetlands) region in Pernambuco, significant differences $(p<0.05)$ were observed between the lots, showing average values of 10.6 to $13.4 \mathrm{~mm}$ for the length, 6.3 to $9.2 \mathrm{~mm}$ for the width, and 6.3 to $7.8 \mathrm{~mm}$ for the thickness, respectively (Silva Junior et al., 2012). In the results that were observed by Silva Junior et al. (2012), the seeds from the Caatinga region were smaller than the seeds from both sources in this current study.

Similar values of length, width, and thickness were observed in studies that evaluated two seed lots from the semiarid regions of Rio Grande do Norte, with 13.0 to $13.4 \mathrm{~mm}$ for the length, 8.0 to $8.6 \mathrm{~mm}$ for the width, and 7.8 to $8.1 \mathrm{~mm}$ for the thickness, and from a lot in Paraíba, with an average of $12.54 \mathrm{~mm}$ for the length, $8.15 \mathrm{~mm}$ for the width, and $7.66 \mathrm{~mm}$ for the thickness (Silva et al., 2008; Bento et al., 2010). 
Seed size could be an indicator of vigor in some species; however, the physiological aspects have a greater influence in germination (Ambika et al., 2014; Snider et al., 2016).

\subsection{Physiological Potential}

For the seed physiological analyses, the seeds from Sergipe, 2012 (SE12) had higher results in germination and vigor parameters when compared to Pernambuco, 2008 (PE08) (Figure 1). These results could indicate a higher deterioration of the PE08 seeds, due to longer storage time. The E. velutina seeds have shown in another study, a reduction of $25 \%$ in viability after only one year of storage (Pereira et al., 2014).
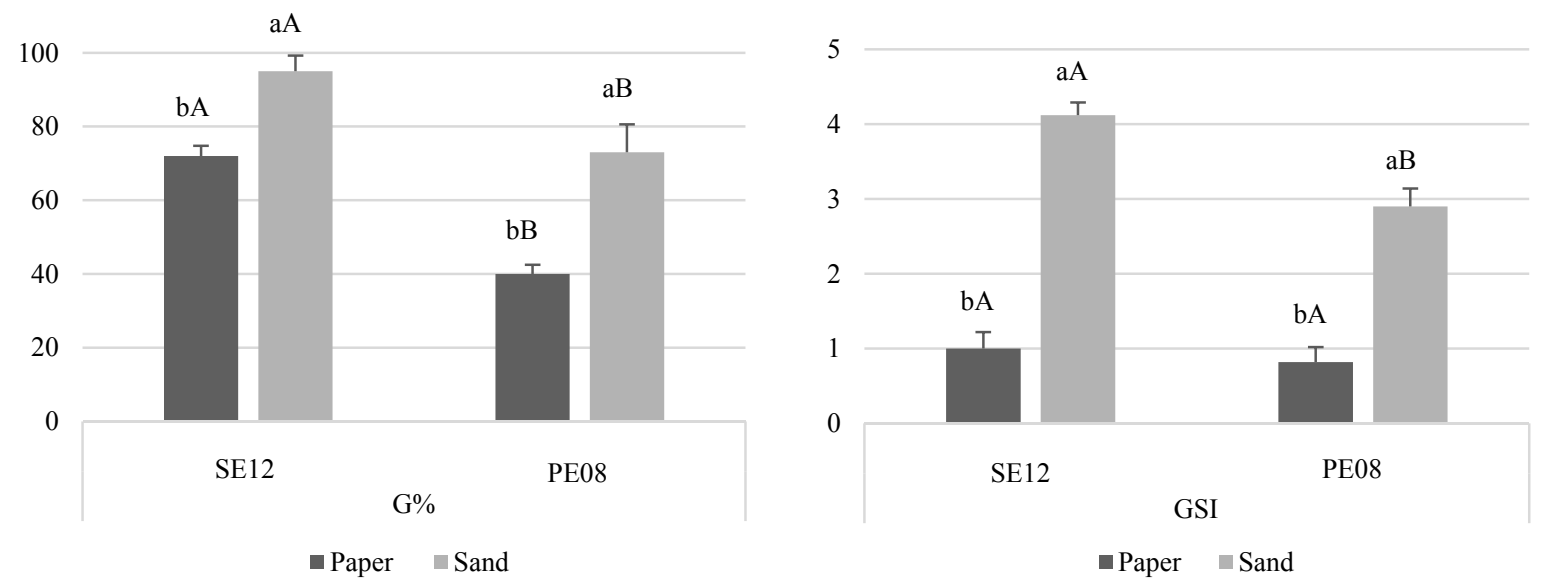

Figure 1. Germination percentage (G\%) and Germination Speed Index (GSI) of the Erythrina velutina Willd. seeds from Pernambuco, 2008 (PE08) and Sergipe, 2012 (SE12) sown on paper and in sand. Means followed by the same lowercase letter did not differ in the substrate and followed by the same uppercase letter did not differ in the provenance by the Tukey test $(\mathrm{p}<0.05)$

For both provenances, the best germination results occurred when using sand as a substrate, as there was a higher influence on germination from fungi proliferation on paper. Other studies with Erythrina species have also shown superior results of germination and seedling development in sand, regardless of fungi proliferation (Alves et al., 2008). The SE12 provenance seeds had a higher viability and vigor results when compared to the PE08 seeds, indicating a deterioration of the material that was stored since 2008.

The PE08 seeds presented $67 \%$ higher electrical conductivity $\left(2.681 \mathrm{mS} \mathrm{cm}^{-1} \mathrm{~g}^{-1}\right)$ when compared to the SE12 $\left(1.602 \mathrm{mS} \mathrm{cm}^{-1} \mathrm{~g}^{-1}\right)$ seeds. Despite being larger, the PE08 seeds were only $8 \%$ bigger and they presented a much higher electrical conductivity. This indicated a higher exudation in the seeds from the Lot PE08. This exudation is probably related to the longer period of storage which contributes to cell membrane systems integrity loss and the leaching of cellular components. In a study of accelerated seed aging it was demonstrated that there was a direct relationship between an increase in the electrical conductivity values and the loss of vigor through ageing in E. velutina seeds (Guedes et al., 2009).

The physiological potential results showed lower vigor for the PE08 seeds. This vigor loss for the orthodox seeds under storage is attributed to the alterations in metabolism and the DNA synthesis, thus affecting the development of the embryo and causing susceptibility to abiotic stress (Ventura et al., 2012; Wang et al., 2014).

\subsection{Drought Stress}

The drought stress tests in laboratory aim to simulate the natural conditions of water restriction, such as in arid and semiarid regions. In order to acquire more conclusive information about the physiological potential of these seeds, the application of vigor tests under drought stress is justified since the objective is to simulate adverse conditions, in which the seeds may be subjected to in the field. The $E$. velutina seeds had variant vigor responses at different times in the -0.8 MPa PEG solution (Figure 2). The analyses showed no interaction between the provenances and the drought stress conditions in the factorial scheme and the results were further analyzed independently. 

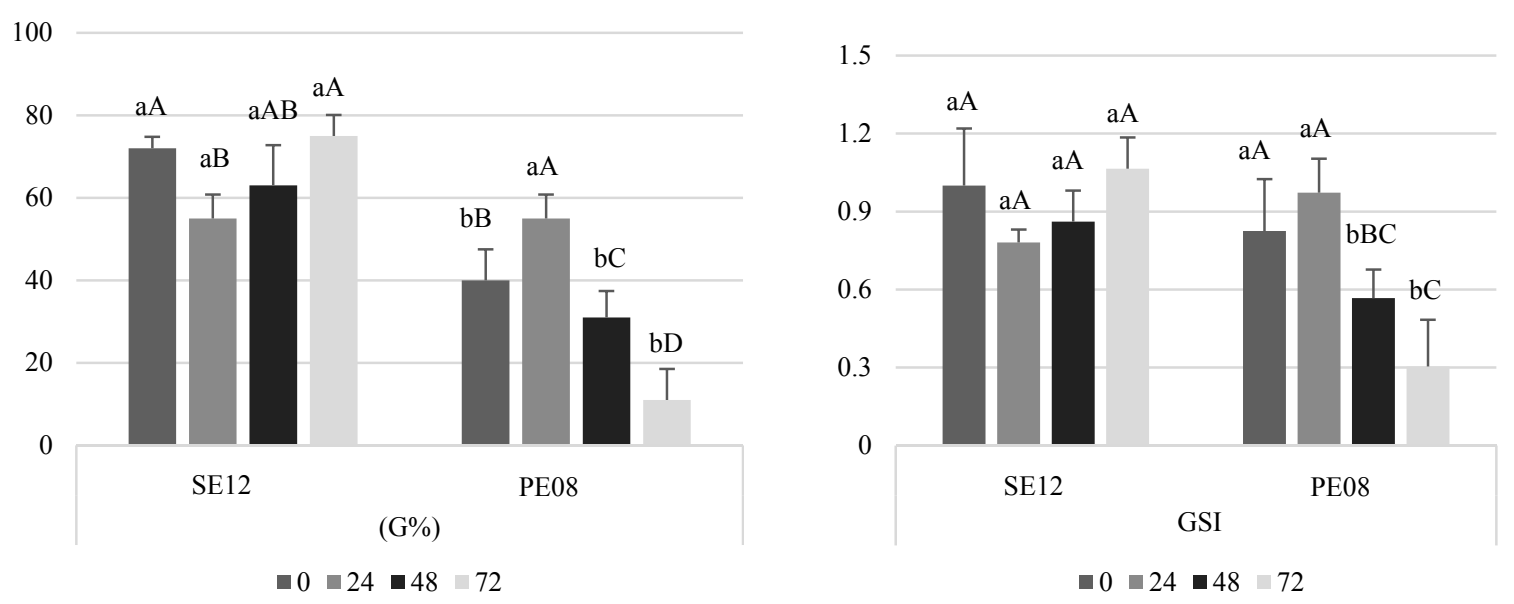

Figure 2. Germination percentage (G\%) and Germination Speed Index (GSI) of the Erythrina velutina Willd. seeds from Pernambuco, 2008 (PE08) and Sergipe, 2012 (SE12), under drought stress in PEG (6000) -0.8 MPa

solution for $0,24,48$, and 72 hours. Means followed by the same lowercase letter did not differ in the provenance and followed by the same uppercase letter did not differ in the treatment by the Tukey test $(\mathrm{p}<0.05)$.

For the SE12 seeds, the increase in time of drought stress on the paper substrate with the PEG solution resulted in increased germination, with its highest values at $72 \mathrm{~h}$. These results were close to germination under ideal conditions of water availability (at $0 \mathrm{~h}$ ). The PE08 seeds had the highest germination percentage and germination speed index at $24 \mathrm{~h}$ of imbibition on the paper substrate with the PEG solution, even better than at the ideal water availability conditions. This result was also confirmed by the Dunnett's test $(\mathrm{p}<0.05)$. For Sesbania virgata (CAV) PERS seeds imbibed in a PEG (8000) solution, the water restriction for $24 \mathrm{~h}$ also had better results in germination (Masetto et al., 2013).

When transferred to ideal water availability conditions, the seeds from both provenances germinated, even after $72 \mathrm{~h}$ of drought stress on the paper substrate with the $-0.8 \mathrm{MPa}$ solution. This showed the tolerance of $E$. velutina to water deficit conditions.

\subsection{RNA Extraction and the Assessment of RNA Integrity}

RNA molecules are vulnerable to oxidation caused by stress; therefore, successful RNA extraction methods should obtain the highest concentration of molecules without contaminants even under such conditions. Studies have shown the degradation of transcripts during storage (Fleming et al., 2017, 2018, 2019) and the PE08 seeds did present the lowest vigor. Therefore, the seeds from Lot PE08 were used to determine viable RNA extraction methods using seed embryos of $E$. velutina under drought stress, even with deteriorated seeds.

The extractions with TRIzol ${ }^{\circledR}$ resulted in higher concentrations of RNA (Figure 3). However, there was a low quality, as indicated by the A260/A280 and the A260/A230 ratios, with protein and/or polysaccharide contamination. For the RNA extraction with the kit, although the quantity was lower than the extraction with $\mathrm{TRIzol}^{\circledR}$, the A260/A280 ratio indicated materials with a high purity (Figure 4). The A260/280 ratio indicates the purity of RNA samples when in relation to contamination with DNA and proteins, with values above 1.8 which indicate high quality materials (Taylor et al., 2010). 


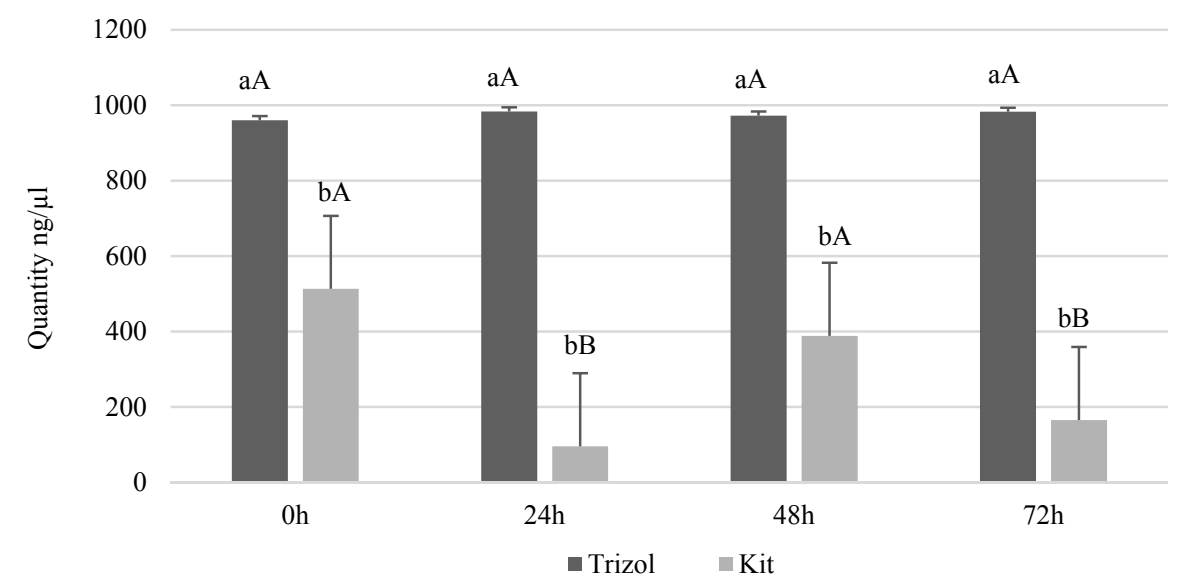

Figure 3. RNA quantity of the Erythrina velutina Willd. seed embryos under drought stress in PEG (6000) -0.8 MPa solution for 0, 24, 48 and 72 hours. Means followed by the same lowercase letter did not differ in method and followed by the same uppercase letter did not differ in treatment by the Tukey test $(p<0.05)$

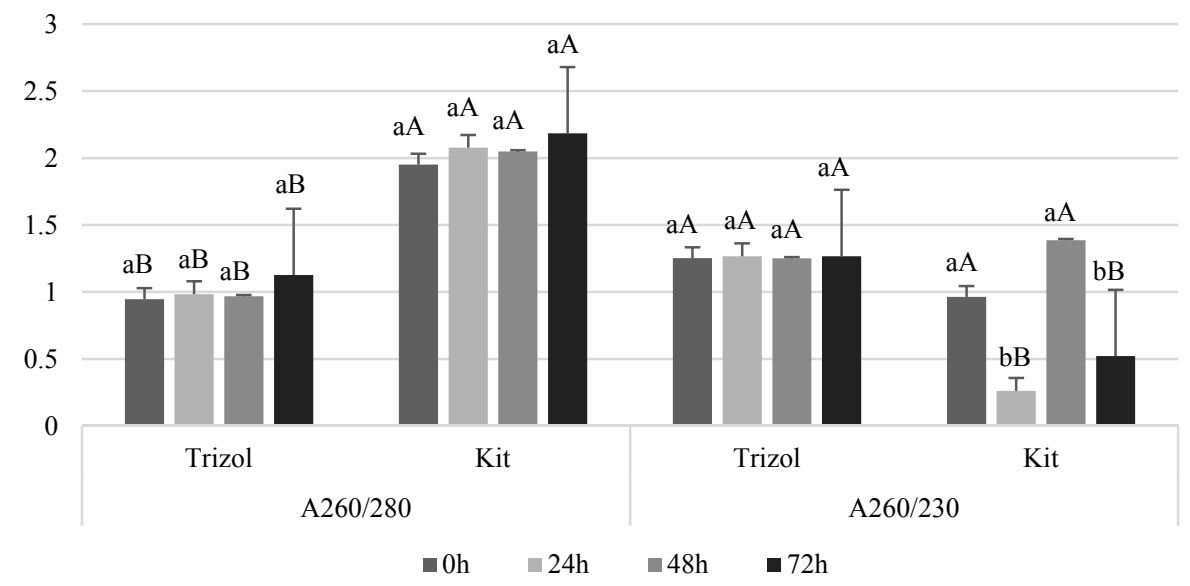

Figure 4. RNA quality of the Erythrina velutina Willd. seed embryos under drought stress in PEG (6000) -0.8 MPa solution for $0,24,48$ and 72 hours. Means followed by the same lowercase letter did not differ in treatment and followed by the same uppercase letter did not differ in method by Tukey test $(\mathrm{p}<0.05)$

During seed maturation, there are high levels of RNA transcripts, which is a determinant of protein synthesis throughout germination (Nelson et al., 2017). The amount of RNA was lower in all seeds under drought stress in comparison to control, except at $48 \mathrm{~h}$, where the amount of RNA was equal to control, as demonstrated by the extraction with the kit. Regardless of the treatment, there was no difference in the quality of RNA when using the A260/280 ratio.

The RNA integrity gels showed $18 \mathrm{~S}$ and $28 \mathrm{~S}$ bands for all samples under drought stress on the paper substrate with PEG and control, and for both TRIzol and commercial kit methods. Highlighted bands were visible for control, indicating the presence of non-degraded RNA on the material. Further biochemical testing could indicate whether the RNA quantity variation was attributed to the drought stress treatment. However, this current study only proposes the evaluation of the extraction methods that are capable of obtaining quality materials for the molecular analyses when using seeds from different provenances, with different physiological potentials.

\section{Conclusions}

The seeds of Erythrina velutina tolerate drought stress as indicated by the assessments of viability and vigor. The imbibition of seeds of E. velutina in the PEG 6000 solution at $-0.8 \mathrm{MPa}$ for 24 hours provides an increase in germination for less vigorous seeds, being an indication of a pre-germinative treatment.

For treated or untreated seeds, the RNA extraction method using a commercial kit is a viable protocol. 


\section{Acknowledgements}

The authors would like to thank the Coordination for the Improvement of Higher Education Personnel (CAPES) for their financial support.

\section{References}

Albuquerque, U. P. de, Medeiros, P. M. de, Almeida, A. L. S. de, Monteiro, J. M., Lins Neto, E. M. de F., Melo, J. G. de, \& Santos, J. P. dos. (2007). Medicinal plants of the caatinga (semi-arid) vegetation of NE Brazil: A quantitative approach. Journal of Ethnopharmacology, 114, 325-354. https://doi.org/10.1016/j.jep.2007. 08.017

Alves, E. U., Andrade, L. A. de, Barros, H. H. de A., Gonçalves, E. P., Alves, A. U., Gonçalves, G. S., ... Cardoso, E. de A. (2008). Substratos para testes de emergência de plântulas e vigor de sementes de Erythrina velutina Willd., Fabaceae. Seminina: Ciências Agrárias, 29, 69-82. https://doi.org/10.5433/ 1679-0359.2008v29n1p69

Ambika, S., Manonmani, V., \& Somasundaram, G. (2014). Review on Effect of Seed Size on Seedling Vigour and Seed Yield. Research Journal of Seed Science, 1-8. https://doi.org/10.3923/rjss.2014.31.38

Aroca, R., Porcel, R., \& Ruiz-Lozano, J. M. (2012). Regulation of root water uptake under abiotic stress conditions. Journal of Experimental Botany, 63, 43-57. https://doi.org/10.1093/jxb/err266

Bento, S. R. S. de O., Santos, A. E. O. dos, Melo, D. R. M. de, \& Torres, S. B. (2010). Eficiência dos testes de vigor na avaliação da qualidade fisiológica de sementes de mulungu (Erythrina velutina Willd.). Revista Brasileira de Sementes, 32, 111-117. https://doi.org/10.1590/S0101-31222010000400012

Claeys, H., \& Inzé, D. (2013). The agony of choice: How plants balance growth and survival under water-limiting conditions. Plant Physiology, 162, 1768-1779. https://doi.org/10.1104/pp.113.220921

Dai, A. G. (2013). Increasing drought under global warming in observations and models. Nature Climate Change, 3, 52-58. https://doi.org/10.1038/nclimate1633

Fleming, M. B., Hill, L. M., \& Walters, C. (2019). The kinetics of ageing in dry-stored seeds: A comparison of viability loss and RNA degradation in unique legacy seed collections. Annals of Botany, 123, 1133-1146. https://doi.org/10.1093/aob/mcy217

Fleming, M. B., Patterson, E. L., Reeves, P. A., Richards, C. M., Gaines, T. A., \& Walters, C. (2018). Exploring the fate of mRNA in aging seeds: Protection, destruction, or slow decay? Journal of Experimental Botany, 69, 4309-4321. https://doi.org/10.1093/jxb/ery215

Fleming, M. B., Richards, C. M., \& Walters, C. (2017). Decline in RNA integrity of dry-stored soybean seeds correlates with loss of germination potential. Journal of Experimental Botany, 68, 2219-2230. https://doi.org/10.1093/jxb/erx100

Guedes, R. S., Alves, E. U., Gonçalves, E. P., Viana, J. S., Buno, R. de L. A., \& Colares, P. N. Q. (2009). Resposta fisiológica de sementes de Erythrina velutina Willd. ao envelhecimento acelerado. Semina: Ciências Agrárias, 30, 323-330. https://doi.org/10.5433/1679-0359.2009v30n2p323

Hohl, M., \& Schopfer, P. (1991). Water Relations of Growing Maize Coleoptiles. Plant Physiology, 95, $716-722$. https://doi.org/10.1104/pp.95.3.716

ISTA (International Seed Testing Association). (2006). International Rules for Seed Testing. ISTA, Switzerland.

Ji, H., Liu, L., Li, K., Xie, Q., Wang, Z., Zhao, X., \& Li, X. (2014). PEG-mediated osmotic stress induces premature differentiation of the root apical meristem and outgrowth of lateral roots in wheat. Journal of Experimental Botany, 65, 4863-4872. https://doi.org/10.1093/jxb/eru255

Jisha, K. C., Vijayakumari, K., \& Puthur, J. T. (2013). Seed priming for abiotic stress tolerance: An overview. Acta Physiologiae Plantarum, 35, 1381-1396. https://doi.org/10.1007/s11738-012-1186-5

Maguire, J. D. (1962). Speed of germination-Aid in selection and evaluation for seedling emergence and vigor 1. Crop Science, 2(2), 176-177. https://doi.org/10.2135/cropsci1962.0011183X000200020033x

MAPA (Ministério da Agricultura, Pecuária e Abastecimento). (2009). Regras para análise de sementes. Brasília, DF: MAPA/ACS.

Marchioro, M., Blank, M. de F. A., Mourão, R. H. V., \& Antoniolli, Â. R. (2005). Anti-nociceptive activity of the aqueous extract of Erythrina velutina leaves. Fitoterapia, 76, 637-642. https://doi.org/10.1016/j.fitote. 2005.07.002 
Masetto, T. E., Faria, J. M. R., Fraiz, A. C. R., \& Rezende, R. K. S. (2013). Condicionamento osmótico de sementes de Sesbania virgata (CAV) PERS. Cerne, 19, 629-636. https://doi.org/10.1590/S0104-77602013 000400013

Nelson, S. K., Ariizumi, T., \& Steber, C. M. (2017). Biology in the dry seed: Transcriptome changes associated with dry seed dormancy and dormancy loss in the arabidopsis GA-insensitive sleepy1-2 mutant. Frontiers Plant Science, 8, 1-21. https://doi.org/10.3389/fpls.2017.02158

O’Donnell, N. H., Møller, B. L., Neale, A. D., Hamill, J. D., Blomstedt, C. K., \& Gleadow, R. M. (2013). Effects of PEG-induced osmotic stress on growth and dhurrin levels of forage sorghum. Plant Physiology and Biochemistry, 73, 83-92. https://doi.org/10.1016/j.plaphy.2013.09.001

Oliveira, G. de, Araújo, M. B., Rangel, T. F., Alagador, D., \& Diniz-Filho, J. A. F. (2012). Conserving the Brazilian semiarid (Caatinga) biome under climate change. Biodiversity and Conserv, 21, 2913-2926. https://doi.org/10.1007/s10531-012-0346-7

Paparella, S., Araújo, S. S., Rossi, G., Wijayasinghe, M., Carbonera, D., \& Balestrazzi, A. (2015). Seed priming: state of the art and new perspectives. Plant Cell Reports, 34, 1281-1293. https://doi.org/10.1007/ s00299-015-1784-y

Patanè, C., Saita A., \& Sortino O. (2013). Comparative Effects of Salt and Water Stress on Seed Germination and Early Embryo Growth in Two Cultivars of Sweet Sorghum. Journal of Agronomy and Crop Science, 199, 30-37. https://doi.org/10.1111/j.1439-037X.2012.00531.X

Pereira, A. M. S., Souza, V. T. A., Coppede, J. da S., França, S. de C., Bertoni, B. W., \& Souza, A. V. V. de. (2014). Seed Germination and Production of Erythrina mulungu and Erythrina velutina Plantlets. American Journal of Plant Sciences, 5, 535-540. https://doi.org/10.4236/ajps.2014.55068

Pereira, E. P. L., Ribeiro, P. R., Loureiro, M. B., Castro, R. D. de, \& Fernandez, L. G. (2014). Effect of water restriction on total phenolics and antioxidant properties of Amburana cearensis (Fr. Allem) A. C. Smith cotyledons during seed imbibition. Acta Physiologiae Plantarum, 36, 1293-1297. https://doi.org/10.1007/ s11738-014-1503-2

Reis, R. C. R., Dantas, B. F., \& Pelacani, C. R. (2012). Mobilization of reserves and germination of seeds of Erythrina velutina Willd. (Leguminosae-Papilionoideae) under different osmotic potentials. Revista Brasileira de Sementes, 34, 580-588. https://doi.org/10.1590/S0101-31222012000400008

Salah, S. M., Yajing, G., Dongdong, C., Jie, L., Aamir, N., Qijuan, H., ... Jin H. (2015). Seed priming with polyethylene glycol regulating the physiological and molecular mechanism in rice (Oryza sativa L.) under nano-ZnO stress. Scientific Reports, 1-14. https://doi.org/10.1038/srep14278

Sano, N., Rajjou, L., North, H. M., Debeaujon, I., Marion-Poll, A., \& Seo, M. (2016). Staying alive: Molecular aspects of seed longevity. Plant and Cell Physiology, 57, 660-674. https://doi.org/10.1093/pcp/pcv186

Santos, L. W. dos, Coelho, M. de F. B., Azevedo, R. A. B., Lima, A. K. B., \& Souza, J. W. N. de. (2013a). Erythrina velutina Willd. Fabaceae: Tree multiple uses in the Brazilian northeast. Revista Verde de Agroecologia e Desenvolvimento Sustentável, 8, 72-80.

Santos, L. W. dos, Coelho, M. de F. B., Maia, S. S. S., Silva, R. C. P. da, Cândido, W. dos S., \& Silva, A. C. da. (2013b). Armazenamento e métodos para a superação da dormência de sementes de mulungu. Semina: Ciências Agrárias, 34, 171-178. https://doi.org/10.5433/1679-0359.2013v34n1p171

Silva Junior, V. T., Lima, J. M. G. M., Rodrigues, C. W. M. S., \& Barbosa, D. C. A. (2012). Erythrina velutina Willd. (Leguminosae-Papilionoideae) ocorrente em Caatinga e Brejo de Altitude de Pernambuco: Biometria, embebição e germinação. Revista Árvore, 36, 247-257. https://doi.org/10.1590/S0100-67622012000200006

Silva, K. B., Alves, E. U., Bruno, R. de L. A., Matos, V. P., \& Gonçalves, E. P. (2008). Morfologia de frutos, sementes, plântulas e plantas de Erythrina velutina Willd., Leguminoseae-Papilionideae. Revista Brasileira de Sementes, 30, 104-114. https://doi.org/10.1590/S0101-31222008000300014

Snider, J. L., Collins, G. D., Whitaker, J., Chapman, K. D., \& Horn, P. (2016). The impact of seed size and chemical composition on seedling vigor, yield, and fiber quality of cotton in five production environments. Field Crops Research, 193, 186-195. https://doi.org/10.1016/j.fcr.2016.05.002

Taylor, S., Wakem, M., Dijkman, G., Alsarraj, M., \& Nguyen, M. (2010). A practical approach to RT-qPCR-Publishing data that conform to the MIQE guidelines. Methods, 50(4), S1-S5. https://doi.org/ 10.1016/j.ymeth.2010.01.005 
Ventura, L., Donà, M., Macovei, A., Carbonera, D., Buttafava, A., Mondoni, A., ... Balestrazzi, A. (2012). Understanding the molecular pathways associated with seed vigor. Plant Physiology and Biochemistry, 60, 196-206. https://doi.org/10.1016/j.plaphy.2012.07.031

Wang, W. Q., Liu, S. J., Song, S. Q., \& Møller, I. M. (2014). Proteomics of seed development, desiccation tolerance, germination and vigor. Plant Physiology and Biochemistry, 86, 1-15. https://doi.org/10.1016/ j.plaphy.2014.11.003

\section{Copyrights}

Copyright for this article is retained by the author(s), with first publication rights granted to the journal.

This is an open-access article distributed under the terms and conditions of the Creative Commons Attribution license (http://creativecommons.org/licenses/by/4.0/). 